\title{
MHC structure and function - antigen presentation. Part 1
}

\author{
Estrutura do MHC e função - apresentação de antígenos. Parte 1
}

\author{
Anna Carla Goldberg ${ }^{1}$, Luiz Vicente Rizzo ${ }^{1}$
}

\begin{abstract}
The setting for the occurrence of an immune response is that of the need to cope with a vast array of different antigens from both pathogenic and non-pathogenic sources. When the first barriers against infection and innate defense fail, adaptive immune response enters the stage for recognition of the antigens by means of extremely variable molecules, namely immunoglobulins and T-cell receptors. The latter recognize the antigen exposed on cell surfaces, in the form of peptides presented by the HLA molecule. The first part of this review details the central role played by these molecules, establishing the close connection existing between their structure and their antigen presenting function.
\end{abstract}

Keywords: Major histocompatibility complex; Antigen presentation; HLA genes; Immune response

\section{RESUMO}

0 cenário no qual ocorre a resposta imune é o da necessidade de fazer frente a uma vasta gama de antígenos diferentes, de fontes patogênicas e não patogênicas. Quando as primeiras barreiras contra infecção e a defesa inata falham, a resposta imune adaptativa entra em campo, para efetuar o reconhecimento dos antígenos, utilizando, para esse fim, moléculas extremamente variáveis, que são as imunoglobulinas e os receptores de células-T. Estes últimos reconhecem 0 antígeno, exposto na superfície das células como peptídeo apresentado pelas moléculas HLA. A primeira parte desta revisão detalha o papel central dessas moléculas, estabelecendo a conexão que existe entre a estrutura e a função de apresentação de antígenos.

Descritores: Complexo principal de histocompatibilidade; Apresentação do antígeno; Genes HLA; Resposta imune

\section{HLA MOLECULES: A DIRECT CONNECTION BETWEEN STRUCTURE AND ANTIGEN PRESENTING FUNCTION}

In the mammalian genome and, more specifically, in the human genome the most variable region known forms the Major Histocompatibility Complex (MHC) that carries a great number of different loci coding for functional genes. Some of these genes also exhibit many variants (alleles), characterizing an extremely polymorphic region. ${ }^{(1)}$ These genes belong to the human leukocyte antigen (HLA) system and code for the major molecules in charge of antigen presentation on the cell surface. The HLA system was described by J. Dausset, in 1958, in a work which earned him the Nobel Prize, in 1980. ${ }^{(2)}$ Up to April 2014, a total of 11,225 sequenced alleles were known throughout the world, all found in the 30 HLA genes located in the MHC genomic region (http://www.ebi.ac.uk/ipd/imgt/hla/stats.html). Of note, though the genes are called HLA, many authors use MHC to designate the molecules resulting from the expression of these genes, and both names will be used throughout this text.

In humans, the MHC region is approximately 4,000-kb-long, located on the short arm of chromosome 6 (6p 21.3). These genes, whether or not expressed, are arranged in three genomic regions or classes. The more distal region corresponds to MHC class I, which carries the genes that code for the classic (1a) class I HLA- A, $-B$, and $-\mathrm{C}$ heavy chains. An extraordinary degree of

\footnotetext{
'Hospital Israelita Albert Einstein, São Paulo, SP, Brazil.

Corresponding author: Anna Carla Goldberg - Avenida Albert Einstein, 627/701, 2ss floor, building A - Zip code: 05651-901 - São Paulo, SP, Brazil - Phone.: (55 11) 2151-1233 - E-mail: goldberg@einstein.br Received on: Mar 27, 2014 - Accepted on: June 26, 2014
}

DOI: 10.1590/S1679-45082015RB3122 
polymorphism characterizes these genes (2,735 alleles at HLA-A, 3,455 alleles at HLA-B and 2,259 alleles at HLA-C loci), and the vast majority of these alleles are functional. There are also so-called non-classic HLA loci coding for the expressed, though less variable, genes HLA- E, -F, -G, HFE, and the MHC class I Chainrelated MICA and MICB. With the notable exception of the MIC genes, all class I HLA (HLAI) molecules form heterodimers with the invariant $\beta 2$-microglobulin chain, coded by a gene on chromosome 15 . All nucleated cells express class I molecules on their cell surface.

On the other hand, class II MHC genes, coding for both chains that will form the functional heterodimer, HLA-DR, HLA-DQ, HLA-DP, HLA-DM, and HLA-DO $(2,649$ known alleles) are located in the more centromeric portion of the MHC region. Initially denominated Ir (from immune response), from early on these genes were recognized for their control of the immune response. (3) They exhibit restricted expression, being predominantly expressed on antigen-presenting cells (APC), such as macrophages, dendritic cells, Langerhans and Kupffer cells, as well as B lymphocytes. Some cells exhibit class II HLA (HLAII) under certain anomalous conditions. This is the case for thyrocytes ${ }^{(4)}$ and intestinal epithelial cells ${ }^{(5)}$ where the expression is induced during inflammatory processes.

A third genomic region, located between the two, carries numerous genes unrelated to $\mathrm{MHC}$, some of which have important immunological functions. Wellknown examples are $\mathrm{CBF}, \mathrm{C} 2$, and $\mathrm{C} 4 \mathrm{~A}$ complement genes, a group of tumor necrosis factor (TNF), and heat shock protein 70 (HSP70) chaperoning genes. ${ }^{(6,7)}$ The list of the many additional genes includes peptide transporter proteins TAP1 and TAP2, and PSMB8 and PSMB9 genes that code for components of the $\beta$-immunoproteasome, to which we will return later in this text. ${ }^{(8)}$ The genomic organization of the $\mathrm{MHC}$ region is an essential feature to understand how the expression and forming of the HLA molecules are regulated and coupled to their antigen presenting function.

Both class I and class II genes present different regulatory sequences located in their upstream (5') portion that guarantee constitutive transcription and cytokine-induced regulation of expression, but some are also shared by HLA genes of the same class, and therefore, allow parallel transcription. HLA genes are also regulated by class-specific trans-activators, respectively $\mathrm{CITA}^{(9)}$ and CIITA, ${ }^{(10)}$ and the ubiquitous nuclear factor kappa $\mathrm{B}(\mathrm{NF}-\mathrm{Kb})$ is a HLAI regulator shared with many other genes. These and other factors carry out the fine-tuning of HLA molecule production and function in each tissue or cell type.

HLAI and HLAII proteins exhibit strong structural similarity. Just like the class I heterodimer formed by an $\alpha$ heavy chain and $\beta 2$-microglobulin, class II molecules are also heterodimers formed by $\alpha$ and $\beta$ chains, coded by A and B genes, respectively. In the class II MHC region, we find only HLA-DRA1, but depending on the haplotype (set of genes found on the same chromosome stretch) one or more expressed HLA-DRB genes may be seen. Therefore, some haplotypes carry one sole HLA-DRB1 functional allele whereas others carry additional expressed alleles at the HLA-DRB3, 4, or 5 loci. All these DRB genes exhibit a high degree of polymorphism. For example, 1,091 different DR beta chains are known. On the other hand, HLA-DQA1 and HLA-DQB1, HLA-DPA1, and HLA-DPB1 loci, all polymorphic, form HLA-DQ and HLA-DP heterodimers, both in cis and in trans, with similar but not identical structure and function to HLA-DR. Non-classic class II genes form the invariant molecules HLA-DO and HLA-DM, which carry out highly specialized functions in peptide presentation.

Each of us carries a pair of chromosomes 6 hence will express on the surface of a single antigen-presenting cell 1 or 2 HLA-A, 1 or 2 HLA-B, 1 or 2 HLA-C, several HLA $1 \mathrm{~b}$, in addition to 1 to 4 HLA-DR, 1 to 4 HLA-DQ, 1 to 4 HLA-DP molecules, comprising hundreds of thousands different units. ${ }^{(11,12)}$ As each of us carries a unique set of HLA genes, the array of possible combinations expressed by each individual in a given population is enormous. This HLA diversity allied to the multiplicity of alleles leads to the extraordinary potential of antigen presentation not only in one individual, but in a group of individuals, a concept extended to a whole population.

In contrast with this variability, the basic design of an HLAI or HLAII molecule is quite similar, forming a goblet anchored to the cell membrane by way of one or two chains, as short chain $\beta 2$-microglobulin confers stability without attaching to the membrane. The external part of the goblet, comprising domains alpha 1 and 2 in the class I molecules and domains alpha 1 and beta 1 in the class II molecules, exhibits a groove, made up of a floor composed of 8 anti-parallel $\beta$ sheet strands and an $\alpha$-helical border. ${ }^{(13,14)}$ The HLA grooves have pockets where the antigen-derived peptides (usually 9 amino acids long) are lodged for presentation to the T-cell receptor (TCR). ${ }^{(15)}$ The HLAI groove formed only by the $\alpha$ chain is closed, but the HLAII groove 
formed by the juxtaposition of $\alpha$ and $\beta$ chains is open, which permits the lodging of peptides longer than the groove itself. The original papers referred to above also carry detailed computerized views of these complex molecules.

The uniqueness of this molecular design is highlighted when the thousands of sequences from the known alleles are compared. The variability of the proteins, reflected in the corresponding DNA sequence, is predominantly clustered in certain portions of the genes. These hypervariable regions, as occurs with immunoglobulin receptors and TCR, are found mainly on the external part of the molecule, inside and in the borders of the groove, that is, precisely at the site where the peptides are lodged, in contrast to the rest of the molecule, the alpha 3 domain in the class I molecules and alpha 2 and beta 2 domains in the class II molecules, where the sequence is highly conserved. The amino acids that form the floor and sides of the groove create a motif or pattern, specific for each allelic variant, which defines what kind of peptide will fit into the groove and bind to that HLA molecule. ${ }^{(16)}$ Of note, the peptides need only bind to some of the available residues within the groove leaving the rest of the amino acids in the sequence free. In spite of constraints imposed by the unique motif, this limited anchoring allows an impressive variety of peptides to be presented by each HLA groove. ${ }^{(17)}$

The single most important reason ensuring the success of peptide presentation by HLA molecules becomes clear when we consider the molecules in charge of recognizing the peptide-HLA complex: the TCR.

TCRs are produced by gene rearrangements carried out by a unique enzymatic complex called rag (recombinationactivating gene) where gene segments are joined to form a novel gene coding for alpha, beta, gamma, or delta TCRs whilst eliminating the intervening DNA sequences. For example, to form the beta chain of a TCR, $52 \mathrm{~V}$ (variable) segments, $2 \mathrm{D}$ (diverse) segments, and $13 \mathrm{~J}$ (joining) segments are reshuffled to form a single functional VDJ segment, which will be processed together with a $\mathrm{C}$ (constant) segment to form the final beta chain. This TCR DNA rearrangement is quite random and thus, each T-lymphocyte will express a unique TCR. Researchers calculate that $10^{16} \alpha \beta$ and $10^{18} \gamma \delta$ TCRs can be generated, each with a highly variable portion specifically placed in the part of the molecule contacting the HLA-peptide complex. This ensures a vast array of molecular variants capable of recognizing any presented antigen. In the second part of this review we will show how these antigens are prepared for presentation to the T-lymphocyte in order to guarantee a recognition that will lead to activation and clonal expansion of the T-cells in charge of the adaptive immune response. Finally, the unique design and variability of HLA class I molecules serves also to regulate natural killer (NK) cells by way of a specific group of receptors, the killercell immunoglobulin-like receptors (KIRs). ${ }^{(18)}$ Though peptides have been shown to interfere in the recognition by KIRs, ${ }^{(19)}$ antigen presentation is not involved in the basic functions of these ligand-receptor pairs and is beyond the scope of this article. For more information we refer excellent reviews. ${ }^{(18,20,21)}$

\section{REFERENCES}

1. Complete sequence and gene map of a human major histocompatibility complex. The MHC sequencing consortium. Nature. 1999;401(6756):921-3.

2. Dausset J. The birth of MAC. Vox Sang. 1984;46(4):235-7.

3. Trowsdale J, Campbell RD. Human MHC genes and products. In: Coligan JE, editor. Curr Protoc Immunol. 2001; Appendix 1: Appendix 1K.

4. Wu Z, Biro PA, Mirakian R, Hammond L, Curcio F, Ambesi-Impiombato FS, et al. HLA-DMB expression by thyrocytes: indication of the antigen-processing and possible presenting capability of thyroid cells. Clin Exp Immunol. 1999;116(1):62-9.

5. Hershberg RM, Cho DH, Youakim A, Bradley MB, Lee JS, Framson PE, et al. Highly polarized HLA class II antigen processing and presentation by human intestinal epithelial cells. J Clin Invest. 1998;102(4):792-803.

6. Carroll MC, Katzman P, Alicot EM, Koller BH, Geraghty DE, Orr HT, et al. Linkage map of the human major histocompatibility complex including the tumor necrosis factor genes. Proc Natl Acad Sci U S A. 1987;84(23):8535-9.

7. Sargent CA, Dunham I, Campbell RD. Identification of multiple HTF-island associated genes in the human major histocompatibility complex class III region. EMBO J. 1989;8(8):2305-12.

8. Tanaka K. Role of proteasomes modified by interferon-gamma in antigen processing. J Leukoc Biol. 1994;56(5):571-5. Review.

9. Meissner TB, Li A, Kobayashi KS. NLRC5: a newly discovered MHC class I transactivator (CITA). Microbes Infect. 2012;14(6):477-84

10. Steimle V, Siegrist CA, Mottet A, Lisowska-Grospierre B, Mach B Regulation of MHC class II expression by interferon-gamma mediated by the transactivator gene CIITA. Science. 1994;265(5168):106-9.

11. Yewdell JW, Reits E, Neefjes J. Making sense of mass destruction: quantitating MHC class I antigen presentation. Nat Rev Immunol. 2003;3(12):952-61. Review.

12. Mester G, Hoffmann V, Stevanović S. Insights into MHC class I antigen processing gained from large-scale analysis of class I ligands. Cell Mol Life Sci. 2011;68(9):1521-32. Review.

13. Bjorkman PJ, Saper MA, Samraoui B, Bennett WS, Strominger JL, Wiley DC Structure of the human class I histocompatibility antigen, HLA-A2. Nature. 1987;329(6139):506-12.

14. Kim J, Urban RG, Strominger JL, Wiley DC. Toxic shock syndrome toxin-1 complexed with a class II major histocompatibility molecule HLA-DR1. Science. 1994;266(5192):1870-4.

15. Stern LJ, Brown JH, Jardetzky TS, Gorga JC, Urban RG, Strominger JL, et al. Crystal structure of the human class II MHC protein HLA-DR1 complexed with an influenza virus peptide. Nature. 1994;368(6468):215-21.

16. Sinigaglia F, Hammer J. Defining rules for the peptide-MHC class II interaction. Curr Opin Immunol. 1994;6(1):52-6. Review.

17. Hammer J, Belunis C, Bolin D, Papadopoulos J, Walsky R, Higelin J, et al. High-affinity binding of short peptides to major histocompatibility complex 
class II molecules by anchor combinations. Proc Natl Acad Sci U S A. 1994;91(10):4456-60.

18. Höglund $P$, Brodin P. Current perspectives of natural killer cell education by MHC class I molecules. Nat Rev Immunol. 2010;10(10):724-34. Review.

19. Cassidy SA, Cheent KS, Khakoo SI. Effects of Peptide on NK cell-mediated MHC I recognition. Front Immunol. 2014;5:133. Review.
20. Li Y, Mariuzza RA. Structural basis for recognition of cellular and viral ligands by NK cell receptors. Front Immunol. 2014;5:123. Review.

21. Campbell KS, Purdy AK. Structure/function of human killer cell immunoglobulin-like receptors: lessons from polymorphisms, evolution, crystal structures and mutations. Immunology. 2011;132(3):315-25. Review. 